
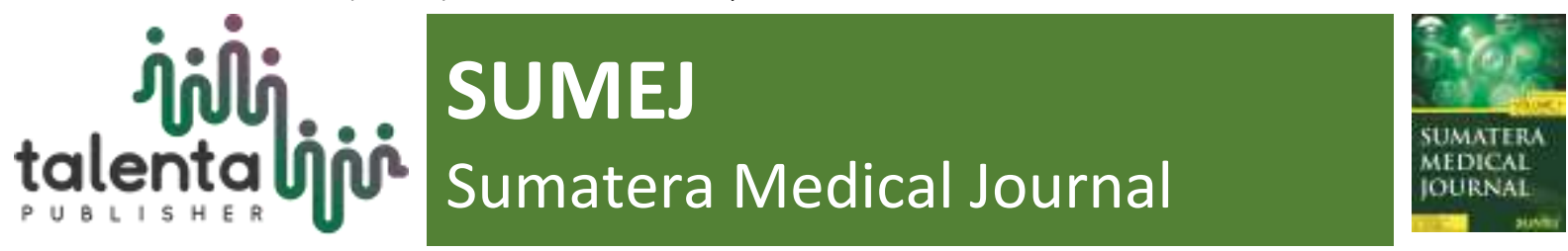

\title{
IHC Expression Relationships MMP7 and VEGF With Normal Ovaries and Ovarian Pathologies
}

\author{
Muhammad Rusda ${ }^{*}$, Riza Rivany ${ }^{2}$, Citra Lestari Hasibuan ${ }^{3}$, Delfi Lutan ${ }^{4}$, \\ Dudy Aldiansyah ${ }^{5}$, Cut Adeya Adella ${ }^{6}$
}

1,2,3,4,5,6 Department of Obstetrics and Gynecology, Faculty of Medicine Universitas Sumatera Utara, Indonesia

\begin{abstract}
To investigate the association of MMP7 and VEGF expression with ovarian cancer, benign ovarian cysts, and normal ovaries. This study was analytical research with case-control design. In the study, IHC expression of MMP7 and VEGF was carried out on paraffin block of ovarian cancer tissue, benign ovarian cyst, and normal ovary. In 40 subjects with ovarian tumors, 17 patients were found with positive MMP7 expression. In the control group, no subjects were found with positive MMP7 expression. There was a significant relationship between MMP7 expression and ovarian tumor incidence. Meanwhile, in 40 subjects with ovarian tumors, 21 patients were found with positive VEGF expression. In the control group, no subjects with positive VEGF expression were found. There was a significant relationship between VEGF expression and ovarian tumor incidence. There was a significant relationship between MMP7 and VEGF expression with ovarian tumor incidence.
\end{abstract}

Keyword: Normal Ovaries, Benign Ovarian Cysts, Ovarian Cancer, MMP7, VEGF

\begin{abstract}
Abstrak. Untuk menyelidiki asosiasi ekspresi MMP7 dan VEGF dengan kanker ovarium, kista ovarium jinak, dan ovarium normal. Penelitian ini merupakan penelitian analitik dengan desain case control. Dalam penelitian, ekspresi IHC MMP7 dan VEGF dilakukan pada blok parafin dari jaringan kanker ovarium, kista ovarium jinak, dan ovarium normal. Pada 40 subjek dengan tumor ovarium, 17 pasien ditemukan dengan ekspresi MMP7 positif. Dalam kelompok kontrol, tidak ada subjek yang ditemukan dengan ekspresi MMP7 positif. Ada hubungan yang signifikan antara ekspresi MMP7 dan kejadian tumor ovarium. Sementara itu, di 40 subjek dengan tumor ovarium, 21 pasien ditemukan dengan ekspresi VEGF positif. Dalam kelompok kontrol, tidak ada subjek dengan ekspresi VEGF positif yang ditemukan. Ada hubungan yang signifikan antara ekspresi VEGF dan kejadian tumor ovarium. Ada hubungan yang signifikan antara MMP7 dan ekspresi VEGF dengan kejadian tumor ovarium.
\end{abstract}

Kata Kunci: Ovarium Normal, Kista Ovarium jinak, Kanker ovarium, MMP7, VEGF

Received 4 January 2019 | Revised 17 January 2019 | Accepted 31 January 2019

*Corresponding author at: Faculty of Medicine, Universitas Sumatera Utara, Indonesia 


\section{Introduction}

Ovarian cancer is the fifth leading cause of cancer in women by 2014, according to the National Cancer Institute (NCI). Statistically, in the United States, ovarian cancer is diagnosed in 22,000 women and cause 14,000 deaths every year [1].

In Indonesia, based on Center for Data and Information Kementerian Kesehatan RI 2015, prevalence of ovarian cancer in Dharmais Hospital for 4 years was 113 big cases and 22 death cases in 2010, 146 new case and 31 death case in 2011, 144 new case and 27 death case in 2012, 134 new case and 46 death case in 2013 [2].

The number of ovarian cysts in RSUP Haji Adam Malik Medan from January 2012 to December 2013 was 120 cases. The prevalence of ovarian cysts on all occurrences of ovarian tumors in Haji Adam Malik General Hospital Medan in 2012 - 2013 was 12.18\% [3]. In RSU Dr. Pirngadi Medan from January to October 2010, there were 34 people with ovarian cysts in women of childbearing age [4].

The growth of tumors and metastases depends on angiogenesis and lymphogenesis by chemical signals originating from tumor cells at a rapid growth stage. Cancer cells that do not have blood flow grow to $1-2 \mathrm{~mm} 2$ and stop at $2 \mathrm{~mm}$ in diameter. When the tumor grows to a diameter of a few millimeters, the hypoxia and loss of nutrients cause the tumor microenvironment to release an "angiogenic switch" signal to allow tumor growth [5].

MMP is an extracellular proteinase family that targets various ECM proteins. They are involved in the angiogenesis process by breaking the perivascular ECM and liberating the angiogenic factor from ECM. MMP7 is mainly expressed by cancer cells. Therefore, MMP7 acts as a specific signal of cancer cells in the stromal cell component necessary for tumor angiogenesis [6].

VEGF is the main regulator of angiogenesis that promotes cell survival, proliferation, and endothelial cell migration while increasing vascular permeability. Basically, by increasing tumor angiogenesis and increasing vascular permeability, VEGF contributes to the occurrence of peritoneal carcinomatosis associated with malignant ascites formation, which is characteristic of the diagnosis of advanced ovarian cancer [7].

From this background, researchers are interested to investigate the contribution of MMP7 and VEGF on the development of ovarian tumors by performing immune histochemical tests in three groups: normal ovaries, benign ovarian cysts, and ovarian cancer. 


\section{Methodology}

This study was analytical research with case-control design. In the study, immune histochemical expression of MMP7 and VEGF was carried out on paraffin block of ovarian cancer tissue, benign ovarian cyst, and normal ovary.

The sample was part of the study population that had a paraffin block biopsy of ovarian cancer tissue, benign ovarian cyst, and normal ovaries stored in Anatomical Pathology Laboratory of RSUP H. Ad-am Malik Medan. Subjects were paraffin blocks of ovarian cancer tissue and benign ovarian cysts obtained from patients who had undergone gynecological and oncology surgery at RSUP HAM and had been confirmed at Anatomical Pathology Laboratory of FK USU.

While the control group study subjects were nor-mal ovarian tissue paraffin blocks obtained from non-ovarian cyst gynecologic surgery that had previously been confirmed from laboratory results of Anatomical Pathology of FK USU.

\section{Result}

Table 1. Characteristic of Demographies

\begin{tabular}{llll}
\hline Demography Characteristics & $\begin{array}{l}\text { Malignant } \\
\text { Tumor }(\mathrm{n}=20)\end{array}$ & $\begin{array}{l}\text { Benign Tumor } \\
(\mathrm{n}=20)\end{array}$ & $\begin{array}{l}\text { Normal } \\
(\mathrm{n}=20)\end{array}$ \\
\hline Age, mean (SD), year & $50,25(9,83)$ & $37,55(10,50)$ & $\begin{array}{l}51,55 \\
(5,20)\end{array}$ \\
BMI, mean (SD), kg/cm ${ }^{2}$ & $22,27(1,06)$ & $24,48(2,91)$ & $\begin{array}{l}23,55 \\
(2,41)\end{array}$ \\
Menarche, mean (SD), year & 11,4 & $11,35(1,50)$ & 11,95 \\
& $(1,35)$ & & $(1,19)$ \\
Pregnancy status, $\mathrm{n}(\%)$ & $10(50)$ & $5(25)$ & 0 \\
Nullipara & $6(30)$ & $3(15)$ & 0 \\
Primigravida & $4(20)$ & $12(60)$ & $20(100)$ \\
Multigravida & & & $7(35)$ \\
Menopause, $\mathrm{n}(\%)$ & $7(35)$ & $17(85)$ & $13(65)$ \\
Not yet & $13(65)$ & $3(15)$ & \\
Already & & & \\
\hline
\end{tabular}


Table 2. Histopathologic Distribution based on Ovarian Malignancy

\begin{tabular}{lc}
\hline Histopathologic Findings & $\mathrm{n}(\%)$ \\
\hline $\begin{array}{l}\text { Malignant Tumor } \\
\text { Adenocarcinoma } \\
\text { mucinosum } \\
\text { Adenocarcinoma }\end{array}$ & $11(55)$ \\
$\quad \begin{array}{l}\text { Serosum } \\
\text { Endometrioid } \\
\text { carcinoma }\end{array}$ & $8(40)$ \\
Benign Tumor & $1(5)$ \\
$\begin{array}{l}\text { Cysadenoma } \\
\text { musinosum }\end{array}$ & \\
Dermoid cycst & $6(30)$ \\
Endometriosis cycst & \\
Cysadenoma serosum & $5(25)$ \\
\hline
\end{tabular}

Based on the results of the histopathological examination, the most common malignant type was Adenocarcinoma mucinosum of 11 people (55\%), followed by Adenocarcinoma serosum of 8 people (40\%) and Endometrioid carcinoma of 1 person (5\%). In benign tumors, most types of tumors are Cystadenoma musinosum and serosum as many as six people (30\%). Dermoid cysts were found in 5 subjects (25\%). And, endometriosis cysts are present in 3 subjects (15\%).

Table 3. Expression of MMP7 based on Ovarian Tumor Type

\begin{tabular}{llll}
\hline & $\begin{array}{l}\text { Malignant } \\
\text { Tumor }\end{array}$ & $\begin{array}{l}\text { Benign } \\
\text { Tumor }\end{array}$ & Normal \\
\hline $\begin{array}{llll}\text { MMP7 Expression } \\
\text { Strong }\end{array}$ & $3(15)$ & $2(10)$ & 0 \\
Medium & $4(20)$ & 0 & 0 \\
Mild & $7(35)$ & $1(5)$ & 0 \\
Negative & $6(30)$ & $17(85)$ & 20 \\
& & & $(100)$
\end{tabular}

VEGF Expression

$\begin{array}{llll}\text { Strong } & 4(20) & 1(5) & 0 \\ \text { Medium } & 7(35) & 0 & 0 \\ \text { Mild } & 2(10) & 7(35) & 0 \\ \text { Negative } & 7(35) & 12(60) & 20 \\ & & & (100)\end{array}$

The results showed that MMP7 expression with the strongest level of malignant tumor was three people (15\%) and in the benign tumor, the group was only two people (10\%). Meanwhile, no strong MMP7 expression was found in subjects with normal ovaries. Negative MMP7 expression in malignant tumors was found in 6 patients (30\%), whereas in the group of benign tumors were present in 17 people (85\%), and in subjects, with normal ovaries, no MMP7 expression was found. 
Table 4. Relationship of MMP7 Expression and VEGF with Ovarian Tumor

\begin{tabular}{lclc}
\hline & $\begin{array}{l}\text { Ovarian } \\
\text { Tumor } \\
(\mathrm{n}=40)\end{array}$ & $\begin{array}{l}\text { Normal/Control } \\
(\mathrm{n}=20)\end{array}$ & $\mathrm{p}^{*}$ \\
\hline MMP7 Expression & & & \\
Positive & $17(42$, & 0 & $<0,001$ \\
Negative & $5)$ & & \\
VEGF Expression & 23 & $20(100)$ & \\
Positive & $(57,5)$ & & $<0,001$ \\
Negative & $21(65)$ & 0 & \\
\hline
\end{tabular}

Fisher's Exact

From 40 subjects with ovarian tumors, 17 patients (42.5\%) were found with positive MMP7 expression. In the control group, no subjects were found with positive MMP7 expression. Using Fisher's exact test, there was a significant relationship between MMP7 expression and ovarian tumor incidence $(\mathrm{p}<0.001)$.

Meanwhile, from 40 subjects with ovarian tumors, 21 patients (65\%) were found with positive VEGF expression. In the control group, no subjects with positive VEGF expression were found. Using Fisher's exact test, there was a significant relationship between VEGF expression and ovarian tumor incidence $(\mathrm{p}<0.001)$.

\section{Discussion}

Table 1 shows that the mean age of subjects with malignant tumors was 50.25 years, in benign tumor group was 37.55 years, and mean age in control group was 51.55 years. The risk of developing ovarian cancer increases with age. Ovarian cancer is rare at the age of fewer than 40 years. Most often suffered by menopausal women. Incidence begins and increases from the age of 40 years and $80-84$ years. The average occurred at age 63 years, $48 \%$ died at the age of 65 years or older [7], [8].

From the number of parities, in the group of malignant tumors, there were ten people $(50 \%)$, nullipara, whereas in the group of benign tumors there were five people $(25 \%)$ and no nullipara in the control group. The cause of ovarian cysts can be a normal physiological process to a genetic mutation involving a tumor suppressor and growth. Risk factors for ovarian cysts and ovarian cancer include nulliparity (never give birth) and low parity. Several studies have shown that women of parity are estimated to have a 30-60\% lower risk for the occurrence of ovarian cancer [3], [4]. 
A study in Albania found a strong association between nulliparous women and the risk of ovarian cancer. Nulliparous women have a risk of 12.5 times higher than female parity [5].

Table 3 shows that MMP7 expression with the highest level of strongest in the malignant tumor as much as three people (15\%) and in benign tumor group only as much as two people (10\%). Meanwhile, no strong MMP7 expression was found in subjects with normal ovaries. Negative MMP7 expression in malignant tumors was found in 6 patients (30\%), whereas in the group of benign tumors were present in 17 people (85\%), and in subjects, with normal ovaries, no MMP7 expression was found.

Particularly, MMP7 has been shown to increase in $80 \%$ of malignant human ovarian cancers compared with $40 \%$ in normal or benign samples. MMP7 has also been shown to be expressed in stromal ovarian cancer tissue especially in serous cancers. Polymorphism in the MMP7 promoter region has shown that single nucleotide polymorphisms in MMP7 are significantly higher in ovarian cancer patients than in controls. Also, MMP7 serum levels were higher in patients with serous and musinous ovarian cancers compared with controls [9].

Based on VEGF measurements, it was found that VEGF expression with the highest level was found in the subjects group with four malignant tumors (20\%), whereas in subjects with the benign tumor, only one person (5\%). Negative expression in the malignant tumor group was also found in 7 patients.

A study conducted in Philadelphia found that malignant neoplasms have a VEGF level 24 times higher than benign cysts and six times higher than borderline lesions. VEGF levels in malignant tumors are about $7.3-97.5 \mathrm{ng} / \mathrm{ml}$ while in non-aligned lesions between undetectable to very low. VEGF levels in borderline lesions are three times higher than benign lesions [5].

\section{REFERENCES}

[1] L. Al-Alem and T. Curry, "Ovarian cancer: involvement of the matrix metalloproteinases," Reproduction, p. REP-14, 2015.

[2] E. I. Deryugina and J. P. Quigley, "Tumor angiogenesis: MMP-mediated induction of intravasation-and metastasis-sustaining neovasculature," Matrix Biology, vol. 44, pp. 94$112,2015$.

[3] D. Eriyanti, "Prevalensi Kista Ovarium di RSUP Haji Adam Malik Medan Periode Januari 2012-Desember 2013," Prevalensi Kista Ovarium di RSUP Haji Adam Malik Medan Periode Januari 2012-Desember 2013.

[4] T. K. Ito, G. Ishii, H. Chiba, and A. Ochiai, "The VEGF angiogenic switch of fibroblasts is regulated by MMP-7 from cancer cells," Oncogene, vol. 26, no. 51, p. 7194, 2007.

[5] J. LIU and J. C. HOLLAND, "Psychological Aspects of Ovarian Cancer and BRCA Testing," in Diagnosis and Management of Ovarian Disorders (Second Edition), Elsevier, 2004, pp. 545-553.

[6] S. M. Moghaddam, A. Amini, D. L. Morris, and M. H. Pourgholami, "Significance of vascular endothelial growth factor in growth and peritoneal dissemination of ovarian cancer," Cancer and Metastasis Reviews, vol. 31, no. 1-2, pp. 143-162, 2012.

[7] N. Nishida, H. Yano, T. Nishida, T. Kamura, and M. Kojiro, "Angiogenesis in cancer," Vascular health and risk management, vol. 2, no. 3, p. 213, 2006. 
[8] D. Siringo-ringo, "KARAKTERISTIK PENDERITA KISTA OVARIUM YANG DIRAWAT INAP DI RUMAH SAKIT ST ELISABETH MEDAN TAHUN 2008-2012,” Gizi, Kesehatan Reproduksi dan Epidemiologi, vol. 2, no. 5, 2013.

[9] Y. Zhang and Q. Chen, "Relationship between matrix metalloproteinases and the occurrence and development of ovarian cancer," Brazilian Journal of Medical and Biological Research, vol. 50, no. 6, 2017. 